\title{
Does Employability Anxiety Trigger Psychological Distress and Academic Major Dissatisfaction? A Study on Tour Guiding Students
}

\author{
Derya Demirdelen Alrawadieh ${ }^{1}[$
}

\begin{abstract}
The tourism and hospitality industry has been severely hit by the ongoing Covid-19 pandemic resulting in much uncertainty about the future of careers within the industry. While current employees have been subject to growing research from different perspectives, little is known about tourism students' (thus potentially future tourism employees) employability anxiety and how this can influence their well-being and attitudes toward their current academic majors. To fill this gap, this study proposes and assesses a conceptual model linking employability anxiety, psychological distress, perceived social support, and academic major satisfaction. Drawing on data collected from tour guiding students in Turkey, the results show that students' employability anxiety was significantly associated with increased psychological distress and decreased academic major satisfaction. The study findings fail to support the proposed moderating effect of perceived social support indicating that when anxious about their vocational future, tour guiding students' levels of psychological distress and academic major dissatisfaction are less likely to be mitigated by perceived social support.
\end{abstract}

\section{Keywords}

Employability anxiety, Psychological distress, Academic major satisfaction, Perceived social support, Tour guiding, Tourism students 


\section{Introduction}

The current Covid-19 pandemic has caused immense disruption to the global tourism and hospitality industry forcing many businesses to downsize and lay off their employees, thus resulting in unprecedented unemployment rates. Travel bans and lockdown orders have brought several tourism jobs, including tour guiding, to a standstill resulting in growing anxiety and stress in the labor market (Demirdelen Alrawadieh, 2021; Chen, 2020). The uncertainty about the future of careers within the industry has never been as salient as during the current crisis. Indeed, it has become apparent that the crisis will contribute to the reconfiguration of the whole tourism and travel industry (Pizam, 2021).

Recent works have addressed various issues related to tourism employees during the crisis (Mao et al., 2020; Park et al., 2020; He et al., 2020). For instance, Chen (2020) noted that the lack of social support and panic about the pandemic resulted in jeopardized well-being, with female and younger employees being more vulnerable to psychological distress. However, while research tends to focus on current tourism employees, little is known about future tourism employees i.e., current tourism students. Specifically, there is an obvious dearth of research which investigates tourism students' employability anxiety and how this can influence their well-being and attitudes toward their current academic majors. Employability anxiety has received some attention in different disciplines (Tomlinson, 2008; Pisarik et al., 2017) and, to a lesser extent, in tourism and hospitality scholarship (Unguren \& Huseyinli, 2020). In the case of tourism students in general and tour guiding students in particular, the relationships between employability anxiety, psychological distress, and academic major satisfaction remain unclear. Specifically, to the best knowledge of the author, the relationship between employability anxiety and academic major satisfaction has not been addressed in tourism education scholarship. This is important because it enhances our understanding of tourism students' expectations and helps void the gap between higher education institutions and the industry.

With these thoughts in mind, the aim of this study is to empirically test a conceptual model linking employability anxiety of tour guiding students with psychological distress, academic major satisfaction and perceived social support (see Figure 1). The proposed model shows that employability anxiety has a direct effect on psychological distress and academic major satisfaction. The model also proposes a moderating effect of perceived social support on the relationship between employability anxiety and psychological distress as well as on the relationship between employability anxiety and academic major satisfaction. By examining these relationships, the study aims to provide higher education institutions offering tourism-related programs with fresh insights into how employability anxiety can bring about negative impacts influencing not only the well-being of tourism students but also harm their attitudes towards their academic majors. The study also scrutinizes the role of social support as a potential factor mitigating the adverse impacts of employability anxiety. 
The contributions of the study are two-fold: First, the study examines the potential effect of employability anxiety on psychological distress and academic major satisfaction. Despite the importance of understanding these relationships for both industry practitioners and policymakers, there has been no previous study investigating this issue, a surprising omission in the existing body of literature. Second, abundant research highlights the role of social support in curbing unfavorable experiences and behaviors within the tourism industry (Alrawadieh et al., 2021; Karatepe, 2010), however, there has been little understanding of the moderating effect of perceived social support on the relationship between employability anxiety and psychological distress as well as on the relationship between employability anxiety and academic major satisfaction. Finally, the study makes an incremental contribution by drawing on the case of tour guiding students, a largely neglected segment that is worth investigation considering the nature of tour guiding being a crucial job in the travel industry with distinct characteristics (Alrawadieh et al., 2020; Cetin \& Yarcan, 2017).

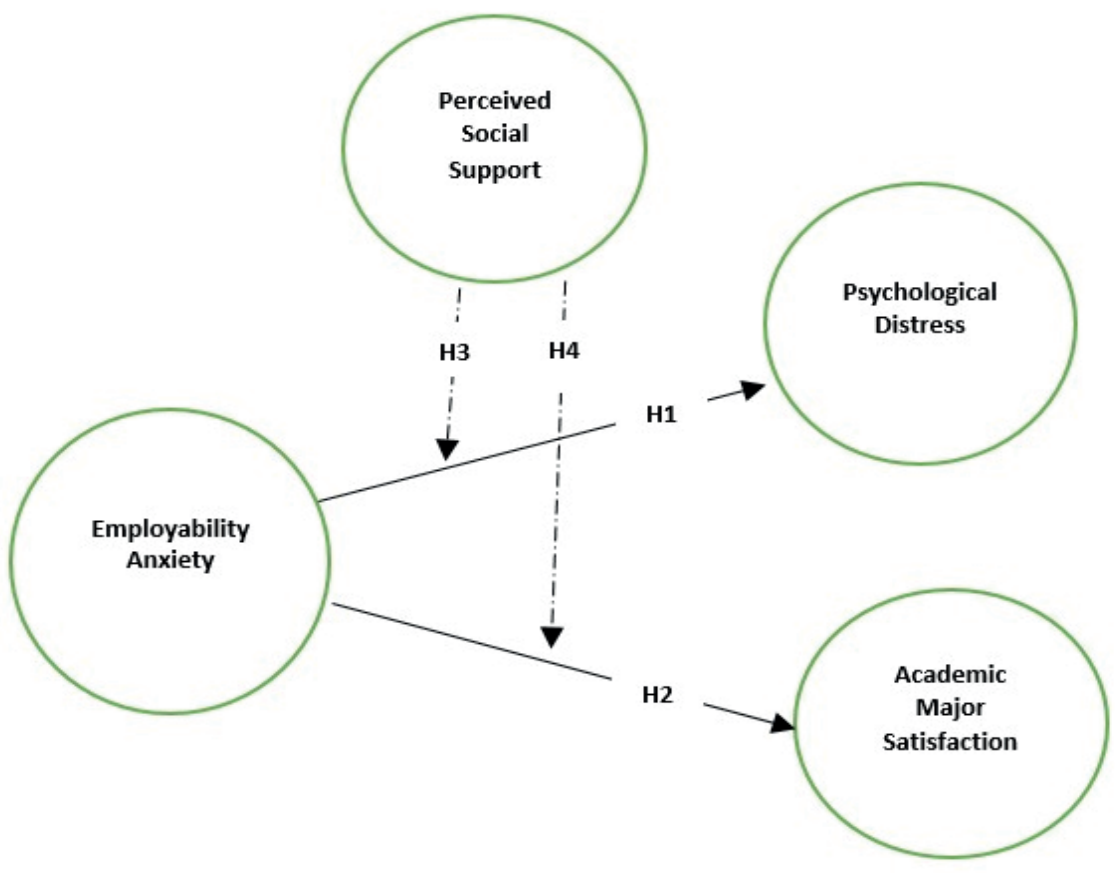

Figure 1. Conceptual Model 


\section{Literature review}

\section{Employability anxiety}

Anxiety refers to the status of discomfort that an individual may feel in his or her personal life (Vidon \& Rickly, 2018). While individuals might be anxious from time to time over various stages of their life, employability anxiety after graduation is seen as one of the important problems especially for university students (Unguren \& Huseyinli, 2020). Therefore, it is important to investigate the causes of anxiety given its potential role in affecting students' career choice and other related decisions (Daniels et. al., 2011; Vignoli, 2015). Although it is common for students to occasionally feel anxious about their career plans after graduation (Tsai et al., 2017), the current Covid-19 pandemic may have led to increased anxiety. For more than one and a half years now, the Covid-19 pandemic has impacted tourism in all aspects (Gössling et al., 2020). The current crisis may also cause uncertainty for tourism students and give rise to concerns about their future plans. The fragile nature of the tourism sector renders it vulnerable to crises, both nationally and internationally (Yeh, 2020; Kaushal \& Srivastava, 2021). While previous studies show that crises can potentially cause anxiety among current tourism employees (Park et al., 2020; Aguiar-Quintana et. al. 2021), one may safely assume that the uncertainty brought by the current crisis can significantly affect current tourism students, a good number of whom may be the tourism employees of the future. Therefore, understanding their employability anxiety and its consequences is of significant importance.

\section{Psychological distress}

Psychological distress is defined as a response to threats that may arise (Jordan et al., 2015). Psychological distress is argued to trigger many negative outcomes such as depression, frustration, anxiety, and failure (Chan, 2006; Verger et. al., 2009). Reducing the destructive effects of stress is important to enhance the quality of life of individuals (Jordan et al., 2019). Psychological distress as experienced by students has also been subject to investigation in previous research (Burris et al., 2009; Stallman, 2010; Delara \& Woodgate, 2015; Sharp \& Theiler, 2018). Existing literature, however, remains limited on students' stress levels and anxiety about finding a job after graduation. While unemployment and employability anxiety can be a key source of distress (Chen, 2020), in times of crises, this anxiety might be more salient, especially for tourism students, given the devastating impacts of the current crisis on tourism and travel industry (Škare et al., 2021).

\section{Academic Major Satisfaction}

Defined as “enjoyment of one's role or experiences as a student” (Lent et al., 2019: 87), academic major satisfaction is of significant importance given that satisfaction in 
this specific domain can potentially affect overall life satisfaction (Sovet et al., 2014; Bücker et al., 2018). This is unsurprising since individuals highly value a satisfactory job and career opportunity as an integral part of their daily life (Nauta, 2007). Despite its role in creating jobs and being appealing to students as a major over the globe, tourism is often sensitive to crises such as the current Covid-19 pandemic. Travel bans and limited mobility have not only harmed the tourism sector and tourism employees (Gössling et al., 2020) but also seem to influence students who major in tourism-related programs. Therefore, it is possible that tourism students' positive attitudes towards their current majors can be impaired due to the uncertainty about their vocational future. In a recent study, Unguren and Huseyinli (2020) collected data just before the outbreak of the pandemic and concluded that students who perceive the structural characteristics of the tourism sector would negatively experience more work anxiety after graduation. One may assume that this negativity is even more salient now with the tourism employment supply experiencing a sharp decline due to the pandemic.

\section{Perceived Social Support}

Social support can be defined as "the exchange of intra-individual resources, e.g., feedback, action support, information exchange, listening, and encouragement, during the exchange of individual resources, e.g., emotional, instrumental, and recreational resources" (Lin et. al., 2014: 246). Zimet et al. (1988) identify three dimensions of social support. These constitute the sources of social support and include family, friends and other important people in our lives. The presence of such individuals and the social support received from them are deemed crucial to help cope with negative situations such as stress, anxiety, and depression (Grey et al., 2020). Social support is also important in eliminating adverse situations influencing students' lives. While previous research highlights the importance of social support in reducing negative stressors and in enhancing the quality of life of students (Kim et al., 2018; Stallman et al., 2018; Alorani \& Alradaydeh, 2018; Alsubaie et al., 2019), it remains unclear how social support can moderate the negative effect of employability anxiety on students' psychological distress and potential regret with university choice (i.e., academic major dissatisfaction). It is therefore important to explore this issue especially in times of crises where social support is much more needed (Grey et al., 2020).

\section{Theoretical background and hypotheses development}

University students may frequently experience negative situations such as depression, anxiety, and stress (Stallman, 2010; Mahmoud et al., 2012; Alsubaie et al., 2019). Employability anxiety among university students has also been subject to investigation in the literature (Pisarik et al., 2017). For instance, in their study on university students from different departments, Tayfun and Korkmaz (2016) noted 
that there was a positive and significant relationship between students' employment anxiety and stress. In tourism research, although there are limited insights into employability anxiety (Unguren \& Huseyinli, 2020), the relationship between employability anxiety and psychological distress among tourism students remains unexplored. The Covid-19 pandemic has introduced a new reality whereby several jobs such as tour guiding are under threat (Bajrami et al., 2021; Kaushal \& Srivastava, 2021). This may potentially influence how current tour guiding students view their future jobs, which may eventually result in psychological distress. Based on this discussion, the following hypothesis is proposed:

$\mathbf{H}_{1}$ : Employability anxiety of tour guiding students is positively associated with psychological distress.

Previous research has investigated academic major satisfaction across different disciplines (Lent et al., 2007; Doo \& Park, 2019). In the field of tourism, there has been a considerable number of studies examining tourism students' attitudes towards working in the sector (Kusluvan \& Kusluvan, 2000; Eren \& Aydin, 2020), career choices of tourism graduates (Richardson, 2009), career preferences (Kim et al., 2010) and career development (Chen \& Shen, 2012). However, the relationship between employability anxiety and academic major satisfaction has received little attention. Kurnaz and Kurnaz (2018), for instance, noted that tour guiding students willingly chose their major and reported low anxiety among students. Koc (2019) however, suggested that social anxiety was a fairly prevalent phenomenon among tourism and hospitality students. We argue that the current crisis has largely re-shaped tourism students' attitudes. One may assume that, when students see current tourism employees lose their jobs or are unable to take tours (in the case of freelancer tour guides), they would feel anxious about the future and thus would be less satisfied with their academic major decisions. Therefore, the following hypothesis is established:

$\mathbf{H}_{2}$ : Employability anxiety of tour guiding students is negatively associated with academic major satisfaction.

Perceived social support is argued to enhance the quality of life (Helgeson, 2003) and well-being (Awang et al., 2014) and it may reduce stress, anxiety, and regret (Zhou et al., 2013). Chen (2020) emphasizes that social support is important in dealing with negative events and situations that may arise in human life. Social support is especially necessary for students to overcome various problems in university life. In this context, students need the presence and support of special people such as friends and family. One may assume that the stronger the social support students receive, the more likely their anxiety and stress will decrease. Civitci (2015) noted that students can cope more easily against stress with the support they receive from family and friends. Likewise, it is not uncommon that students rely on social ties such as family 
members when deciding what to major in. Therefore, it is likely that perceived social support can reduce the negative effect of employability anxiety on academic major satisfaction. Based on the aforementioned discussion, the following hypotheses are proposed.

$\mathbf{H}_{3}$ : Perceived social support moderates the relationship between employability anxiety and psychological distress.

$\mathbf{H}_{4}$ : Perceived social support moderates the relationship between employability anxiety and academic major satisfaction.

\section{Methodology}

\section{Study context}

Tour guides are acknowledged as key players in the tourism and travel industry. Their knowledge, competency, and skills are important assets to ensure favorable tourist experiences (Güzel et al., 2020), thus raising the need to place more importance on current tour guiding students. To be an official tour guide in Turkey, candidates should receive a formal education, pass a foreign language proficiency test, and participate in applied tours in specific regions or across the country (TUREB, 2021). Despite the challenging and multi-stage nature of the tour guiding profession (Demirdelen Alrawadieh, 2021), the number of students enrolling in tour guiding programs is increasing. In the academic year 2019-2020, the number of students enrolled in tourism and hospitality-related programs in Turkey was over 85,300 of which around $12 \%$ were enrolled in tour guiding programs (YÖK, 2021). Therefore, tour guiding seems to be an attractive profession among tourism students.

\section{Measures}

Multi-items scales from the previous literature were used to measure the constructs employed in the framework. Academic major satisfaction was measured using seven items adapted from Sainfort and Booske (2000) and Schlegel et al. (2013). The items were given on a 5-point Likert-type scale, with the end poles labeled as "strongly disagree (1)" and "strongly agree (5). Sample items included "I am comfortable with my decision". Nine items were also adapted from Unguren and Huseyinli (2020) to measure employability anxiety. The construct was measured on a 5-point Likert-type scale, anchored from strongly disagree (1) to strongly agree (5). Sample items included "The idea of being left unemployed after graduation scares $m e$ ". Psychological distress was operationalized using six items from Tomitaka et al. (2017). Respondents were asked the following question: "During the past 30 days, about how often did you feel" and their answers were measured on a 5-point Likert- 
type scale ranging from " $1=$ none of the time" to " $5=$ all of the time". Finally, 12 items were adapted from Zimet et al. (1988) to measure the perceived social support. The items were given on a 5-point Likert-type scale, with the end poles labeled as "strongly disagree (1)" and "strongly agree (5). Sample items included "There is a special person who is around when I am in need". The survey also collected some socio-demographic data.

\section{Sampling and data collection}

The population of the current study is composed of students majoring in tour guiding in Turkey. In the 2019-2020 academic year, there were around 11 thousand students enrolled on different programs in tour guiding across Turkey. The present study used a self-administered questionnaire to collect data from tour guiding students. The data collection was initiated on February 8, 2021 and was completed on 25 March 2021. By the end of the data collection, 130 useable questionnaires were obtained. To assess the sample adequacy, the rule of thumb stating that the minimum sample size should be 10 times the maximum number of arrowheads pointing at a latent variable in the model (Henseler et al., 2009) was adopted. Therefore, a minimum of 120 cases was sufficient to test the proposed model in the current study. Hence, the sample size (130) is deemed adequate. Respondents were recruited from undergraduate students affiliated to a tour guiding program in a major university in Istanbul, Turkey. Filling the questionnaire took less than 10 minutes. The questionnaire consisted of two sections; the first section aimed to collect demographic data about the respondents, whereas the second section aimed to measure the constructs. The demographic profile of the respondents is presented in Table 1. Despite the challenging and demanding nature of tour guiding especially for females (Alrawadieh \& Demirdelen Alrawadieh, 2020), the sample was split almost equally between females and males. Almost all the respondents mentioned that they willingly chose to major in tour guiding.

Table 1

Demographic Profile of Participants

\begin{tabular}{lcc}
\hline Variables & $\mathbf{N}=(\mathbf{1 3 0})$ & Percentage \\
\hline Gender & 66 & 50,8 \\
Female & 64 & 49,2 \\
Male & & \\
Willingly majoring? & 129 & 99,2 \\
Yes & - & - \\
No & 1 & 0,8 \\
Not sure & & \\
Order of Major & 108 & 83,1 \\
$1^{\text {st }}$ choice & 15 & 11,5 \\
$2^{\mathrm{d}}$ choice & 7 & 5,4 \\
$3^{\mathrm{d}}$ and over &
\end{tabular}




\section{Findings and discussion}

\section{Measurement model assessment}

Before testing the structural model, the reliability and validity of the measurement model were assessed. Reliability is ensured considering the factor loadings, Composite Reliability (CR) values, Cronbach's Alpha ( $\alpha$ ), and rho-A values. As a rule of thumb, factor loadings should be above 0.7 (Hair et al., 2017). However, if AVE and convergent validity are not negatively affected, items with factor loadings of 0.6 can also be retained (Hair et al., 2017). As shown in Table 2, Composite Reliability (CR), Cronbach Alpha, and rho-A values are all above 0.7. After removing 1 EA and 1 AMS, the CR values are between 0.89 and 0.94, the Cronbach Alpha values are between 0.86 and 0.93 , and the rho-A values are between 0.88 and 0.95 . Therefore, the reliability of the measurement model is established.

Table 2

Validity and Reliability

\begin{tabular}{|c|c|c|c|c|c|}
\hline Construct & $\begin{array}{c}\text { Fac. } \\
\text { loadings }\end{array}$ & $\begin{array}{c}\text { Cronbach } \\
(\alpha)\end{array}$ & Rho_A & CR & AVE \\
\hline Academic Major Satisfaction & & 0.936 & 0.959 & 0.949 & 0.758 \\
\hline AMS1: My decision is sound. & 0.790 & & & & \\
\hline AMS2: I am completely confident I made the right decision. & 0.875 & & & & \\
\hline AMS3: I am completely satisfied with the decision. & 0.916 & & & & \\
\hline AMS4: I am comfortable with my decision. & 0.912 & & & & \\
\hline $\begin{array}{l}\text { AMS5: This decision is consistent with my core values and } \\
\text { beliefs. }\end{array}$ & 0.890 & & & & \\
\hline $\begin{array}{l}\text { AMS6: I am confident I will not regret choosing this major } \\
\text { in the future. }\end{array}$ & 0.834 & & & & \\
\hline Employability Anxiety & & 0.934 & 0.938 & 0.946 & 0.689 \\
\hline EA1: I am concerned about my future after graduation. & 0.799 & & & & \\
\hline $\begin{array}{l}\text { EA2: The thought of not being able to find a job after } \\
\text { graduation makes me feel anxious. }\end{array}$ & 0.887 & & & & \\
\hline EA3: I clearly don't know what to do after graduation. & 0.848 & & & & \\
\hline $\begin{array}{l}\text { EA4: I think it will be difficult to find a job after } \\
\text { graduation, in the field I want and in conditions I need. }\end{array}$ & 0.901 & & & & \\
\hline $\begin{array}{l}\text { EA5: The idea of being left unemployed after graduation } \\
\text { scares me. }\end{array}$ & 0.856 & & & & \\
\hline $\begin{array}{l}\text { EA6: I think I will have difficulties in finding a job in the } \\
\text { field from which I graduated and in conditions I want. }\end{array}$ & 0.906 & & & & \\
\hline $\begin{array}{l}\text { EA7: I think I can easily find a job in the area I want after } \\
\text { graduation.* }\end{array}$ & 0.681 & & & & \\
\hline EA9: I am not worried about finding a job after graduation.* & 0.732 & & & & \\
\hline Psychological Distress & & 0.864 & 0.882 & 0.899 & 0.599 \\
\hline PD1: Nervous & 0.722 & & & & \\
\hline PD2: Hopeless & 0.842 & & & & \\
\hline PD3: Restless or fidgety & 0.624 & & & & \\
\hline PD4: So depressed that nothing could cheer you up & 0.858 & & & & \\
\hline PD5: That everything was an effort & 0.822 & & & & \\
\hline PD6: Worthless & 0.752 & & & & \\
\hline Perceived Social Support & & 0.925 & 0.938 & 0.927 & 0.517 \\
\hline $\begin{array}{l}\text { SS1: There is a special person who is around when I am in } \\
\text { need. }\end{array}$ & 0.656 & & & & \\
\hline
\end{tabular}




\begin{tabular}{ll}
\hline SS2: There is a special person with whom I can share my & 0.683 \\
joys and sorrows. & 0.690 \\
SS3: My family really tries to help me. & 0.669 \\
SS4: I get the emotional help and support I need from my & 0.736 \\
family. & \\
SS5: I have a special person who is a real source of comfort & 0.682 \\
to me. & 0.803 \\
SS6: My friends really try to help me. & 0.707 \\
SS7: I can count on my friends when things go wrong. & 0.768 \\
SS8: I can talk about my problems with my family. & \\
SS9: I have friends with whom I can share my joys and & 0.758 \\
Sorrows. & \\
SS10: There is a special person in my life who cares about & 0.681 \\
my feelings. & 0.774 \\
SS11: My family is willing to help me make decisions. & \\
SS12: I can talk about my problems with my friends. &
\end{tabular}

*reverse coded items

Validity is established by assessing the convergent validity and discriminant validity of the measures. To ensure convergent validity, the average explained variance (AVE) value for each of the constructs in the model should be higher than 0.5. As seen in Table 2, AVE values are between 0.51 and 0.75 indicating that convergent validity is established. For discriminant validity, Fornell-Larcker criterion and Hetero-TraitMono-Trait (HTMT) values were used (Henseler et al., 2015; Voorhees et al., 2016). According to the Fornell-Larcker criterion, the square root of the average explained variance (AVE) values should be larger than the correlations with the other variables. According to the Heterotrait-Monotrait (HTMT) criterion, the HTMT value should be lower than 85 (Henseler et al., 2015). As seen in Table 3, the discriminant validity is established using both methods.

Table 3

Discriminant Analysis

\begin{tabular}{lcccc}
\hline \multicolumn{5}{c}{ Fornell-Larcker Criterion } \\
\hline Construct & $\mathbf{1}$ & $\mathbf{2}$ & $\mathbf{3}$ & $\mathbf{4}$ \\
\hline Academic Major Satisfaction & 0.871 & & & \\
Employability Anxiety & -0.447 & 0.830 & & \\
Psychological Distress & -0.127 & 0.563 & 0.774 & 0.719 \\
Perceived Social Support & 0.293 & -0.268 & -0.175 & $\mathbf{4}$ \\
& Heterotrait-Monotrait (HTMT) Criterion & \\
& $\mathbf{1}$ & $\mathbf{2}$ & $\mathbf{3}$ & \\
\cline { 2 - 5 } Academic Major Satisfaction & & & & \\
Employability Anxiety & 0.462 & & \\
Psychological Distress & 0.141 & 0.616 & & \\
Perceived Social Support & 0.305 & 0.225 & 0.163 & \\
\hline
\end{tabular}

\section{Structural Model Assessment}

After establishing the outer measurement model, the inner measurement model (i.e., structural model) was assessed. The Bootstrap 500 method was performed to 
test the hypothesized relationships. As shown in Table 4, all the direct hypotheses proposed were confirmed. Employability anxiety of tour guiding students was found to have a positive and significant effect on psychological distress $(\beta=0.56, p<0.01)$ thus supporting H1. The results also show that the employability anxiety of tour guiding students has a negative and significant effect on academic major satisfaction $(\beta=-0.40, p<0.01)$. Hence, $\mathrm{H} 2$ was accepted.

Table 4

Hypothesis Testing

\begin{tabular}{lcllll}
\hline Hypothesis & Direction & Beta & T-value & P value & Result \\
\hline H1 & $\begin{array}{c}\text { Employability } \\
\text { Anxiety } \rightarrow \\
\text { Psychological } \\
\text { Distress } \\
\text { Employability } \\
\text { Anxiety } \rightarrow\end{array}$ & 0.561 & 8.508 & 0.000 & Supported \\
H2 & -0.400 & 5.948 & 0.000 & Supported \\
& $\begin{array}{l}\text { Academic Major } \\
\text { Satisfaction }\end{array}$ & & & & \\
\hline
\end{tabular}

\section{Assessment of the Moderating Effect}

The proposed model suggests that perceived social support can moderate the impact of employability anxiety on psychological distress and academic major satisfaction. Table 5 shows that, contrary to our prediction, the moderating effect of perceived social support was not confirmed $(\beta=0.04, P>0.05 ; \beta=0.09, P>0.05)$. Hence, $\mathrm{H} 3$ and $\mathrm{H} 4$ were rejected.

\section{Table 5}

Assessment of the Moderating Effect

\begin{tabular}{|c|c|c|c|c|c|}
\hline Hypothesis & Interaction Term & Beta & T-value & $P$ value & Result \\
\hline$\overline{\mathrm{H} 3}$ & $\begin{array}{c}\text { Perceived } \\
\text { Social Support } \\
* \text { Employability } \\
\text { Anxiety } \rightarrow \\
\text { Psychological Distress }\end{array}$ & 0.044 & 0.457 & 0.648 & Rejected \\
\hline $\mathrm{H} 4$ & $\begin{array}{c}\text { Perceived } \\
\text { Social Support } \\
* \text { Employability } \\
\text { Anxiety } \rightarrow \text { Academic } \\
\text { Major Satisfaction }\end{array}$ & 0.096 & 0.947 & 0.344 & Rejected \\
\hline
\end{tabular}

\section{Conclusions}

Previous research focusing on tourism students indicates that students may experience high uncertainty and anxiety (Koc, 2019; Ramakrishnan \& Macaveiu, 2019). The Covid-19 pandemic has introduced a new reality raising the need for more research addressing tourism students' anxiety as well as their attitudes towards their current majors. Drawing on data collected from tour guiding students in Turkey, this 
study has proposed and assessed a conceptual model linking employability anxiety, psychological distress, perceived social support, and academic major satisfaction. The results partially support the proposed model indicating that students' employability anxiety was significantly associated with increased psychological distress and decreased academic major satisfaction but failed to confirm the moderating effect of perceived social support on these relationships. The findings advance our knowledge on the outcomes of employability anxiety and propose some practical implications.

First, by modeling employability anxiety with psychological distress and academic major satisfaction, the study contributes to existing research on career planning (Tsai et al., 2017; Ramakrishnan \& Macaveiu, 2019). Specifically, the study draws on tour guiding students, a largely neglected context. In this vein, the current study is timely given the uncertainty caused by the ongoing pandemic. Second, while previous research underscores the importance of social support in curbing unfavorable workrelated stressors, little is known about the moderating effect of perceived social support on the relationship between employability anxiety and psychological distress as well as on the relationship between employability anxiety and academic major satisfaction.

Drawing on the study's findings, it has become apparent that tourism students are likely to experience greater psychological distress and feel less satisfied with their academic majors when they perceive high uncertainty about their vocational future. While this may be bounded to the current conditions caused by the crisis, higher education institutions may play a significant role in reducing their students' employability anxiety by designing and implementing some programs. For instance, academic staff may be encouraged to invite their students to join available Webinars on resilience strategies in the tourism industry. Communicating successful stories of tour guides who managed to survive the crisis may also help students reduce stress and regain favorable attitudes towards their academic majors. This may also require a stronger collaboration between higher education institutions and industry practitioners (e.g. tour guiding association).

Finally, the present study has some limitations. The data were collected only from tour guiding students. Therefore, the results may not be valid to students majoring in other tourism programs (e.g., hotel management). Given that the data collection coincided with travel bans and lockdown orders, it is likely that students majoring in tour guiding would be less optimistic and more anxious about their vocational future. Therefore, the current study may be confined to important boundary conditions. Future research may revalidate this study after the current crisis and extend the present model by including other variables (e.g., major switching intention, intention to join the industry). 


\section{References}

Aguiar-Quintana, T., Nguyen, H., Araujo-Cabrera, Y., \& Sanabria-Díaz, J. M. (2021). Do job insecurity, anxiety and depression caused by the COVID-19 pandemic influence hotel employees' self-rated task performance? The moderating role of employee resilience. International Journal of Hospitality Management, 94, 102868.

Alorani, O. I., \& Alradaydeh, M. T. F. (2018). Spiritual well-being, perceived social support, and life satisfaction among university students. International Journal of Adolescence and Youth, 23(3), 291-298.

Alrawadieh, Z., \& Demirdelen Alrawadieh, D. (2020). Sexual harassment and wellbeing in tourism workplaces: The perspectives of female tour guides. In Vizcaino-Suárez, P., Jeffrey, H. \& Eger, C. (eds.), Tourism and Gender-Based Violence - Challenging Inequalities (pp.80- 92). CABI, Oxford.

Alrawadieh, Z., Cetin, G., Dincer, M. Z., \& Istanbullu Dincer, F. (2020). The impact of emotional dissonance on quality of work life and life satisfaction of tour guides. The Service Industries Journal, 40(1-2), 50-64.

Alrawadieh, Z., Demirdelen Alrawadieh, D., Olya, H. G., Erkol Bayram, G., \& Kahraman, O. C. (2021). Sexual harassment, psychological well-being, and job satisfaction of female tour guides: the effects of social and organizational support. Journal of Sustainable Tourism, https://doi.org/ $10.1080 / 09669582.2021 .1879819$

Alsubaie, M. M., Stain, H. J., Webster, L. A., \& Wadman, R. (2019). The role of sources of social support on depression and quality of life for university students. International Journal of Adolescence and Youth, 24(4), 484-496.

Awang, M. M., Kutty, F. M., \& Ahmad, A. R. (2014). Perceived social support and well being: firstyear student experience in university. International Education Studies, 7(13), 261-270.

Bajrami, D. D., Terzić, A., Petrović, M. D., Radovanović, M., Tretiakova, T. N., \& Hadoud, A. (2021). Will we have the same employees in hospitality after all? The impact of COVID-19 on employees' work attitudes and turnover intentions. International Journal of Hospitality Management, 94, 102754.

Burris, J. L., Brechting, E. H., Salsman, J., \& Carlson, C. R. (2009). Factors associated with the psychological well-being and distress of university students. Journal of American college health, 57(5), 536-544.

Bücker, S., Nuraydin, S., Simonsmeier, B. A., Schneider, M., \& Luhmann, M. (2018). Subjective well-being and academic achievement: A meta-analysis. Journal of Research in Personality, 74, 83-94.

Cetin, G., \& Yarcan, S. (2017). The professional relationship between tour guides and tour operators. Scandinavian Journal of Hospitality and Tourism, 17(4), 345-357.

Chan, D. W. (2006). Emotional intelligence, social coping, and psychological distress among Chinese gifted students in Hong Kong. High Ability Studies, 16(2), 163-178.

Chen, C. C. (2020). Psychological tolls of COVID-19 on industry employees. Annals of Tourism Research. doi: 10.1016/j.annals.2020.103080 
Chen, T. L., \& Shen, C. C. (2012). Today's intern, tomorrow's practitioner?-The influence of internship programmes on students' career development in the Hospitality Industry. Journal of Hospitality, Leisure, Sport \& Tourism Education, 11(1), 29-40.

Civitci, A. (2015). The moderating role of positive and negative affect on the relationship between perceived social support and stress in college students. Educational Sciences: Theory and Practice, 15(3), 565-573.

Daniels, L. M., Stewart, T. L., Stupnisky, R. H., Perry, R. P., \& LoVerso, T. (2011). Relieving career anxiety and indecision: The role of undergraduate students' perceived control and faculty affiliations. Social Psychology of Education, 14(3), 409-426.

Delara, M., \& Woodgate, R. L. (2015). Psychological distress and its correlates among university students: a cross-sectional study. Journal of pediatric and adolescent gynecology, 28(4), 240244.

Demirdelen Alrawadieh, D. (2021). Kadın turist rehberlerinin karşılaştıkları sorunların belirlenmesine yönelik bir araştırma. Journal of Hospitality and Tourism Issues, 3(1).

Demirdelen Alrawadieh, D. (2021). Mapping the governmental response to Covid-19 pandemic and its implications on the hospitality and tourism industry: The case of Turkey. In Covid-19 Pandemic and the Hospitality and Tourism Industry, What is Next?, Nunkoo, R., D. Gürsoy, M., Sarışık \& E. Boğan (Ed.), Edward Elgar publishers.

Doo, M. Y., \& Park, S. H. (2019). Effects of work value orientation and academic major satisfaction on career decision-making self-efficacy. Higher Education, Skills and Work-Based Learning. 9(4), 550-562.

Eren, R., \& Aydin, A. (2020). Perceptions and attitudes of culinary students towards food and beverage industry in Turkey. Journal of Culinary Science \& Technology, 18(5), 371-395.

Gössling, S., Scott, D., \& Hall, C. M. (2020). Pandemics, tourism and global change: a rapid assessment of COVID-19. Journal of Sustainable Tourism, 29(1), 1-20.

Grey, I., Arora, T., Thomas, J., Saneh, A., Tohme, P., \& Abi-Habib, R. (2020). The role of perceived social support on depression and sleep during the COVID-19 pandemic. Psychiatry Research, 293, 113452.

Güzel, Ö., Nacak, E., Bilgi, E., \& Kalin, V. (2020). Sustainable tourism and the roles of tour guides in destinations: A qualitative case study in turkey. Journal of Economy Culture and Society 62.

Hair Jr, J. F., Hult, G. T. M., Ringle, C., \& Sarstedt, M. (2017). A primer on partial least squares structural equation modeling (PLS-SEM). Sage publications.

He, J., Mao, Y., Morrison, A. M., \& Coca-Stefaniak, J. A. (2020). On being warm and friendly: the effect of socially responsible human resource management on employee fears of the threats of COVID-19. International Journal of Contemporary Hospitality Management, 33(1), 346-366.

Helgeson, V. S. (2003). Social support and quality of life. Quality of life research, 12(1), 25-31.

Henseler, J., Ringle, C. M., \& Sarstedt, M. (2015). A new criterion for assessing discriminant validity in variance-based structural equation modeling. Journal of the Academy of Marketing Science, 43(1), 115-135.

Jordan, E. J., Spencer, D. M., \& Prayag, G. (2019). Tourism impacts, emotions and stress. Annals of Tourism Research, 75, 213-226.

Jordan, E. J., Vogt, C. A., \& DeShon, R. P. (2015). A stress and coping framework for understanding resident responses to tourism development. Tourism Management, 48, 500-512. 
Karatepe, O. M. (2010). The effect of positive and negative work-family interaction on exhaustion: Does work social support make a difference?. International Journal of Contemporary Hospitality Management. 22(6), 836-856.

Kaushal, V., \& Srivastava, S. (2021). Hospitality and tourism industry amid COVID-19 pandemic: Perspectives on challenges and learnings from India. International Journal of Hospitality Management, 92, 102707.

Kim, B. P., McCleary, K. W., \& Kaufman, T. (2010). The new generation in the industry: Hospitality/ Tourism students' career preferences, sources of influence and career choice factors. Journal of Hospitality \& Tourism Education, 22(3), 5-11.

Kim, B., Jee, S., Lee, J., An, S., \& Lee, S. M. (2018). Relationships between social support and student burnout: A meta-analytic approach. Stress and Health, 34(1), 127-134.

Koc, E. (2019). Turkish tourism and hospitality students' social anxiety and avoidance. Journal of Hospitality \& Tourism Education, 31(1), 49-54.

Kurnaz, H. A., \& Kurnaz, A. (2018). Önlisans turist rehberliği eğitimi alan öğrencilerin geleceğe ait düşüncelerinin belirlenmesi: Marmaris Turizm Meslek Yüksekokulu örneği. OPUS Uluslararası Toplum Araştırmalart Dergisi, 8(1), 237-247.

Kusluvan, S., \& Kusluvan, Z. (2000). Perceptions and attitudes of undergraduate tourism students towards working in the tourism industry in Turkey. Tourism Management, 21(3), 251-269.

Lent, R. W., Singley, D., Sheu, H. B., Schmidt, J. A., \& Schmidt, L. C. (2007). Relation of socialcognitive factors to academic satisfaction in engineering students. Journal of Career Assessment, 15(1), 87-97.

Lin, Y. S., Huang, W. S., Yang, C. T., \& Chiang, M. J. (2014). Work-leisure conflict and its associations with well-being: The roles of social support, leisure participation and job burnout. Tourism Management, 45, 244-252.

Mahmoud, J. S. R., Staten, R. T., Hall, L. A., \& Lennie, T. A. (2012). The relationship among young adult college students' depression, anxiety, stress, demographics, life satisfaction, and coping styles. Issues in Mental Health Nursing, 33(3), 149-156.

Mao, Y., He, J., Morrison, A. M., \& Andres Coca-Stefaniak, J. (2020). Effects of tourism CSR on employee psychological capital in the COVID-19 crisis: from the perspective of conservation of resources theory. Current Issues in Tourism, https://doi.org/10.1080/13683500.2020.1770706

Nauta, M. M. (2007). Assessing college students' satisfaction with their academic majors. Journal of Career Assessment, 15(4), 446-462.

Park, E., Kim, W. H., \& Kim, S. B. (2020). Tracking tourism and hospitality employees' real-time perceptions and emotions in an online community during the COVID-19 pandemic. Current Issues in Tourism, https://doi.org/10.1080/13683500.2020.1823336

Pisarik, C. T., Rowell, P. C., \& Thompson, L. K. (2017). A phenomenological study of career anxiety among college students. The Career Development Quarterly, 65(4), 339-352.

Pizam, A. (2021). The Aftermath of the Corona Virus Pandemic, International Journal of Hospitality Management, doi.org/10.1016/j.ijhm.2021.102909.

Ramakrishnan, S., \& Macaveiu, C. (2019). Understanding aspirations in tourism students. Journal of Hospitality and Tourism Management, 39, 40-48.

Richardson, S. (2009). Undergraduates' perceptions of tourism and hospitality as a career choice. International Journal of Hospitality Management, 28(3), 382-388.

Sainfort, F., \& Booske, B. C. (2000). Measuring post-decision satisfaction. Medical Decision Making, 20(1), 51-61. 
Schlegel, R. J., Hicks, J. A., Davis, W. E., Hirsch, K. A., \& Smith, C. M. (2013). The dynamic interplay between perceived true self-knowledge and decision satisfaction. Journal of Personality and Social Psychology, 104(3), 542-558.

Sharp, J., \& Theiler, S. (2018). A review of psychological distress among university students: Pervasiveness, implications and potential points of intervention. International Journal for the Advancement of Counselling, 40(3), 193-212.

Škare, M., Soriano, D. R., \& Porada-Rochoń, M. (2021). Impact of COVID-19 on the travel and tourism industry. Technological Forecasting and Social Change, 163, 120469.

Sovet, L., Park, M. S. A., \& Jung, S. (2014). Validation and psychometric properties of academic major satisfaction scale among Korean college students. Social indicators research, 119(2), 1121-1131.

Stallman, H. M. (2010). Psychological distress in university students: A comparison with general population data. Australian Psychologist, 45(4), 249-257.

Stallman, H. M., Ohan, J. L., \& Chiera, B. (2018). The role of social support, being present and selfkindness in university student well-being. British Journal of Guidance \& Counselling, 46(4), 365-374.

Tayfun, A. N. T., \& Korkmaz, A. (2016). Üniversite öğrencilerinde işsizlik kaygısı: süleyman demirel üniversitesi öğrencileri üzerinde bir araştırma, Mehmet Akif Ersoy Üniversitesi Sosyal Bilimler Enstitüsü Dergisi, 8(17), 534-558.

Tomitaka, S., Kawasaki, Y., Ide, K., Akutagawa, M., Yamada, H., Ono, Y., \& Furukawa, T. A. (2017). Characteristic distribution of the total and individual item scores on the Kessler Screening Scale for Psychological Distress (K6) in US adults. BMC psychiatry, 17(1), 1-12.

Tomlinson, M. (2008). 'The degree is not enough': students' perceptions of the role of higher education credentials for graduate work and employability. British journal of sociology of education, 29(1), 49-61.

Tsai, C. T., Hsu, H., \& Hsu, Y. C. (2017). Tourism and hospitality college students' career anxiety: Scale development and validation. Journal of Hospitality \& Tourism Education, 29(4), 158-165.

Unguren, E., \& Huseyinli, T. (2020). The moderating effect of student club membership on the relationship between career intention in the tourism sector and post-graduate employability anxiety. Journal of Hospitality, Leisure, Sport \& Tourism Education, 27, 100265.

Union of Turkish Tourist Guides (2021). Nasil rehber olunur? Retrivied April 17, 2021, from http:// www.tureb.org.tr/tr/Page/Detail/75

Verger, P., Combes, J. B., Kovess-Masfety, V., Choquet, M., Guagliardo, V., Rouillon, F., \& PerettiWattel, P. (2009). Psychological distress in first year university students: socioeconomic and academic stressors, mastery and social support in young men and women. Social psychiatry and psychiatric epidemiology, 44(8), 643-650.

Vidon, E. S., \& Rickly, J. M. (2018). Alienation and anxiety in tourism motivation. Annals of Tourism Research, 69, 65-75.

Vignoli, E. (2015). Career indecision and career exploration among older French adolescents: The specific role of general trait anxiety and future school and career anxiety. Journal of Vocational Behavior, 89, 182-191.

Voorhees, C. M., Brady, M. K., Calantone, R., \& Ramirez, E. (2016). Discriminant validity testing in marketing: an analysis, causes for concern, and proposed remedies. Journal of the Academy of Marketing Science, 44(1), 119-134. 
Yeh, S. S. (2020). Tourism recovery strategy against COVID-19 pandemic. Tourism Recreation Research, https://doi.org/10.1080/02508281.2020.1805933

Yükseköğretim Kurumu (2021), 2019-2020 Öğretim Y1lı Yükseköğretim İstatistikleri, Retrivied April 17, 2021, from https://istatistik.yok.gov.tr/

Zhou, X., Zhu, H., Zhang, B., \& Cai, T. (2013). Perceived social support as moderator of perfectionism, depression, and anxiety in college students. Social Behavior and Personality: an international journal, 41(7), 1141-1152.

Zimet, G.D., Dahlem, N.W., Zimet, S.G. \& Farley, G.K. (1988). The multidimensional scale of perceived social support. Journal of Personality Assessment, 52, 30-41. 
